\title{
SETTLEMENT OF AN UNIDENTIFIED OYSTER (CRASSOSTREA) AND OTHER EPIBENTHOS ON PLASTIC SUBSTRATES AT A NORTHERN BRAZILIAN MANGROVE ISLAND
}

\author{
GARDUNHO, D. C. L.; GOMES, C. P.; TAGLIARO, C. H. \& BEASLEY, C. R.* \\ Universidade Federal do Pará, Brazil. \\ ${ }^{*}$ Corresponding author: beasley@ufpa.br
}

\begin{abstract}
GARDUNHO, D. C. L.; GOMES, C. P.; TAGLIARO, C. H. \& BEASLEY, C. R. (2012) Settlement of an unidentified oyster (Crassostrea) and other epibenthos on plastic substrates at a northern Brazilian mangrove island. Braz. J. Aquat. Sci. Technol. 16(1): 41-51. elSSN 1983-9057. Management and culture of mangrove oysters may reduce harvesting pressure on natural populations in northern Brazil. Densities of oyster seed, scars and other epibenthos on plastic sheets and bottles were observed over two years at a mangrove island (Ilha Canela), Bragança, Pará, northern Brazil. The only oyster species found settling on the substrates was a possibly exotic oyster (Crassostrea $s p$. canela) that is closely related to Indo-Pacific Crassostrea and that also occurs in southern China. Densities of seed and scars of Crassostrea $s p$. canela on bottles were about half those on sheets. Seed and scars predominated (>95\% relative abundance) on both collectors. Although densities of other epibenthos were low and irregular, these were positively correlated with densities of seed on both collectors. Oyster seed and barnacles on sheets were more abundant in the wet season. However, in the dry season, seed predominated on the inside of bottles, a refuge from predation or desiccation or both, whereas oyster scars and barnacles were more abundant on the outside. The target species for oyster culture in Pará is Crassostrea gasar. Oyster growers are concerned about potential impacts of Crassostrea sp. canela, the larvae of which appear to prefer high salinity. Seed is regular and abundant as densities exceed published figures for several other Crassostrea species. Knowledge of the timing and density of settlement of this oyster and associated epibenthos is important in order to minimize interference during seed collection of target species. The timing and location of seed collection is therefore critical. We also suggest experiments with collectors conditioned with adult Crassostrea gasar shell remnants, as well as those where limited establishment of epibenthos, such as barnacles, has been allowed, in order to maximize spat collection of the target species, C. gasar, along the Pará coast.
\end{abstract}

Keywords: Cupped oyster Spatfall Artificial collectors Encrusting fauna Amazon coast

\section{INTRODUCTION}

Mangroves are important habitats in terms of coastal ecology, providing shelter, food and reproductive areas for many marine and estuarine species (Alongi, 2002). Mangroves also have great socioeconomic importance, sustaining human communities based on coastal fisheries and products derived from the forest (Kathiresan \& Bingham, 2001; Krause et al., 2001; Glaser, 2003; Krause \& Glaser, 2003; Nishida et al., 2006). Their role in providing important ecological services (Kathiresan \& Bingham, 2001), such as coastal protection (Alongi, 2002) and nutrient cycling (Wolff et al., 2000), is also well known. Increasing population growth around the mangroves of northeastern Pará state, northern Brazil, is resulting in greater pressure on coastal resources (Glaser, 2003; Glaser \& Oliveira, 2004).

The recently created Caeté-Taperaçu RESEX, a coastal reserve that allows sustainable extraction of natural resources, supports over 12,000 people and should improve management of the mangroves in the area (Glaser \& Oliveira, 2004). However, more information on the dynamics of mangrove species is needed to make management decisions, such as limits to catches and duration and timing of harvesting periods, for example. Natural populations of oysters are often indiscriminately harvested (Alvarenga \& Nalesso, 2006), leading to their decline (Carranza et al., 2009). In Pará, there is regular recruitment of spat (Marques-Silva et al., 2006) and Crassostrea gasar (Adanson, 1757) (= C. brasiliana (Lamarck, 1819), evidence from molecular studies (Lapègue et al., 2002; Pie et al., 2006; Varela et al., 2007; Lazoski et al., 2011; and see also p. 345 in Carranza et al., 2009)) is successfully cultured in the region. Properly regulated, aquaculture may reduce destructive harvesting of natural beds. However, the latter also need to be managed correctly to maintain or increase their productivity and reproductive output (Dame, 1996), which, in turn is the sole source of seed for oyster culture in Pará (Sampaio, 2007). The coastal ecosystem as a whole would also benefit from better management of this benthic resource (Dame, 1996; Ellison, 2008), which provides a series of ecosystem services (Brumbaugh \& Coen, 2009).

The aims of the present study were to evaluate seasonality in settlement of oysters and potential fouling epibenthos, as well as determine the effectiveness of two different types of plastic seed collectors on settlement, at Ilha Canela, a mangrove island in northern Brazil. The oyster observed settling at Canela was initially believed to be Crassostrea gasar. However, 
subsequent comparison of mitochondrial 16S (Varela et al., 2007) and COI (Melo et al., 2010a) sequences with those in Genbank showed that this oyster belongs to the genus Crassostrea and was provisionally named Crassostrea sp. canela. This oyster is closely related to Indo-Pacific species of Crassostrea (Varela et al., 2007; Melo et al., 2010a). Furthermore, 16S sequences of an unidentified Crassostrea species (Crassostrea sp. 2, GenBank: HQ660984-HQ660988) from southern China (Liu et al., 2011) are 99\% similar to those of Crassostrea sp. canela (GenBank: EF473278, EF473280 \& EF473281). Thus, evidence is growing for the exotic status of Crassostrea sp. canela in Brazil. Genetic evidence shows that the Pacific oyster, Crassostrea gigas, is established in the wild in southern Brazil (Melo et al., 2010b). Exotic oyster species are known to have negative effects on native populations (Carranza et al., 2009). Oyster growers in Pará have noted that Crassostrea sp. canela seed interferes with collection of $C$. gasar seed and the former does not grow well once settled, thus being of little commercial value (Author, pers. obs.). Information on settlement patterns of this oyster species may be important where C. gasar beds supply seed for culture and are in need of restoration.

\section{MATERIAL AND METHODS}

\section{Study area}

Ilha Canela $\left(00^{\circ} 47^{\prime} \mathrm{S}, 46^{\circ} 43^{\prime} \mathrm{W}\right)$ is a small island at the mouth of the Taperaçu estuary, in the Municipality of Bragança, Pará. For maps and brief descriptions of the island, see de Sousa et al. (2008) and Amaral et al. (2001). The wet season is from January to June and the dry season from July to December. The tidal cycle is semi-diurnal with a tidal amplitude of between 3 and 5 meters (Cohen et al., 1999; Schwendenmann et al., 2006). According to local residents, Canela began as a small sand bank about $65-70$ years ago. It now covers an area of $5 \mathrm{~km}^{2}$, most of which is covered by mangrove $(80 \%)$ with the rest composed of saltmarsh, dunes and other vegetation (Amaral et al., 2001). The island is an important bird sanctuary (Rodrigues, 2007) and is protected under municipal law (Lei No.3.280/97) as an Area of Environmental Protection (Área de Proteção Ambiental). At the center of the island $\left(00^{\circ} 47^{\prime}\right.$ 002 " S; $46^{\circ} 43^{\prime} 329^{\prime \prime} \mathrm{W}$ ) is a tidal channel surrounded by mangrove composed of Rhizophora mangle (L.) and Avicennia germinans (L.). Seed collectors were deployed each month in this area as settlement of Crassostrea sp. canela was observed on mangrove prop roots and trunks only along this channel. No known beds of any other Crassostrea species occur close to the study area.

\section{Fieldwork}

A wooden platform, which was exposed at low tides, was erected at the center of the mangrove channel to support two types of seed collector (Figure 1). The first type, sheets, consisted of 20 clear, transparent polyethylene terephthalate (PET) sheets, measuring 18 by $9 \mathrm{~cm}$. Sheets were cut from cylindrical $2 \mathrm{~L}$ soft drinks bottles, so there was a convex and a concave side to each one. Sheets were perforated once in the middle and nylon fishing line was placed through each to form a vertical string of sheets with a space of 5 $\mathrm{cm}$ between adjacent sheets. Sheets were arranged with the concave side down of one sheet facing the concave side up of the next. The second type of collector, bottles, was composed of 10 clear, transparent $600 \mathrm{ml}$ PET bottles. The only modification was a $10 \mathrm{x}$ $0.2 \mathrm{~cm}$ lateral slit to allow the passage of water. Bottles were attached using nylon line around the neck and the bottom of each bottle was $5 \mathrm{~cm}$ above the top of its nearest neighbor. A small weight was used to keep the collectors from floating during high tide. The experiment lasted 24 months, between April 2002 and March 2004, during which time collectors were replaced by new ones every 30 days. After removal, collectors were individually stored in labeled plastic bags in a freezer until examination. Individuals belonging to different epibenthic taxa were counted on each side (convex and concave) of each sheet and on the outside and inside of each bottle. Data were expressed as mean densities (numbers $\mathrm{cm}^{-2}$ ) and standard errors (s.e.) and plotted over time to show monthly variation (pooled over sheet

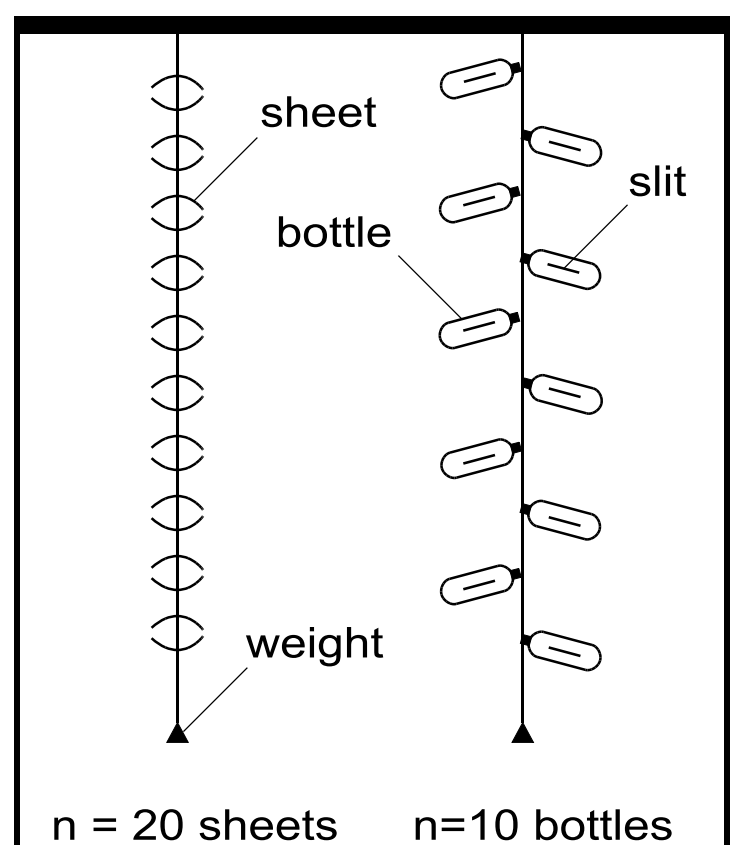

Figure 1 - Schematic diagram showing the arrangement of sheets (left) and bottles (right) deployed for oyster seed collection in a mangrove tidal channel, between April 2002 and March 2004, at Ilha Canela. 
Table 1 - Total epibenthic densities (mean \pm s.e.) on Concave and Convex surfaces of sheets and on External and Internal surfaces of bottles during the Wet and Dry seasons between April 2002 and March 2004, at Ilha Canela. Densities are expressed as number of individuals $\mathrm{cm}^{-2} . \mathrm{n}=$ total number of replicate surfaces examined on sheets and bottles.

\begin{tabular}{llccc}
\hline \hline \multirow{2}{*}{ Collector } & Surface type & $\mathbf{n}$ & Wet & Dry \\
\hline Sheets & Concave & 480 & $1.27 \pm 0.033$ & $1.16 \pm 0.026$ \\
& Convex & 480 & $1.23 \pm 0.033$ & $1.06 \pm 0.022$ \\
Bottles & External & 240 & $0.32 \pm 0.012$ & $0.42 \pm 0.015$ \\
& Internal & 240 & $0.55 \pm 0.011$ & $0.67 \pm 0.013$ \\
\hline \hline
\end{tabular}

and bottle surfaces). Data were also analyzed using 2-way analysis of variance where mean densities of total epibenthos, oyster seed, scars (empty left valve attached to substrate; as a measure of seed mortality), barnacles and other encrusting organisms were compared between seasons (Dry and Wet months, see Study Area for details) and surfaces of sheets (Convex, Concave) or bottles (Inside, Outside). We opted not to test for differences among months due to the complexity of, and increased chance of error in interpreting pairwise comparisons. Analyzes over longer periods may have greater biological relevance due to time lags in changes in salinity and other environmental cues. Diagnostic ANOVA plots were used to check whether assumptions of homoscedasticity and normality were met. Data were log-transformed where necessary. Spearman Rank correlation analysis was used to determine the strength and significance of relationships between variables. All data analyzes were carried out using GNU-R (Ihaka \& Gentleman, 1996; R-project, 2011).

\section{RESULTS}

\section{Taxons found}

Crassostrea sp. canela seed and scars, barnacles (Fistulobalanus citerosum, Henry 1974), and other, rather sporadic, epibenthic organisms such as bivalves Mytella falcata (d'Orbigny, 1846) and Sphenia antillensis Dall \& Simpson, 1901, gastropods Thais sp. and Anachis sp., Bryozoa, Cnidaria, Polychaeta and decapod crustaceans were found on collectors. No other oyster species besides Crassostrea sp. canela was found on collectors, henceforth all oyster seed and scars refer to the latter. In general, relative abundance was greatest for oyster seed (sheets: $61.9 \%$, bottles: $71.9 \%$ ) and scars (sheets: $33.5 \%$, bottles: $27.1 \%$ ) whereas barnacles (sheets: $4.2 \%$, bottles: $0.3 \%$ ) and other epibenthos (sheets: $0.4 \%$, bottles: $0.7 \%$ ) were least abundant. In general, mean densities of oyster seed ranged from $0.16-0.75$ and from $0.074-1.64$ individuals $\mathrm{cm}^{-2}$ on sheets and bottles, respectively.

\section{Monthly variation in settlement}

There was a regular pattern of settlement of oyster seed on sheets with peaks in density around the months of June and January (Figure 2a). Density of seed was lower on bottles and there was less pronounced monthly variation (Figure $2 \mathrm{c}$ ) with peaks around December. The density of oyster scars on both sheets (Figure 2b) and bottles (Figure 2d) was approximately half that of seed and in both cases was positively correlated with the density of seed (sheets: $r_{s}=0.5867, p<0.001$ and bottles: $r_{s}=0.4297$, $p<0.001$ ). Barnacles were predominant during the wet season with highest densities during the months of February on sheets (Figure 3a) and January on bottles (Figure 3c). Densities of barnacles were lower on bottles by a factor of 10 in comparison with sheets. Relatively low densities of other epibenthic organisms occurred on sheets (Figure 3b) and bottles (Figure 3d). Although variable, the monthly pattern in settlement of other epibenthos was positively correlated with that of oyster seed on both sheets $\left(r_{s}=0.0686, p<0.05\right)$ and bottles $\left(r_{s}=0.4408, p<0.001\right)$.

\section{Effects of season and surface type on settlement}

Total epibenthic density was significantly higher in the wet season but with no difference in surfaces on sheets (Tables 1,2). Total density was significantly higher in the dry season on bottles and was significantly higher on the inside of bottles in both seasons (Tables $1,3)$. Density of oyster seed was significantly higher on sheets in the wet season and no differences were found in relation to sheet surfaces (Table 2, Figure 4a). No differences in scar densities were found for either season or sheet surfaces (Table 2, Figure $4 \mathrm{~b}$ ). Barnacle density on sheets was significantly greater in the wet season, the seasonal difference being approximately 10 fold (Table 2, Figure 5a). No differences were found in densities of other epibenthic organisms on sheets (Table 2, Figure 5b).

On bottles, seed and scar densities were greater in the dry season (Table 3, Figures 4c and $4 d)$. However, whereas seed density was greater on the inside of the bottle in both seasons, scar density was significantly greater on the outside, the difference 
(a) Oyster seed on sheets

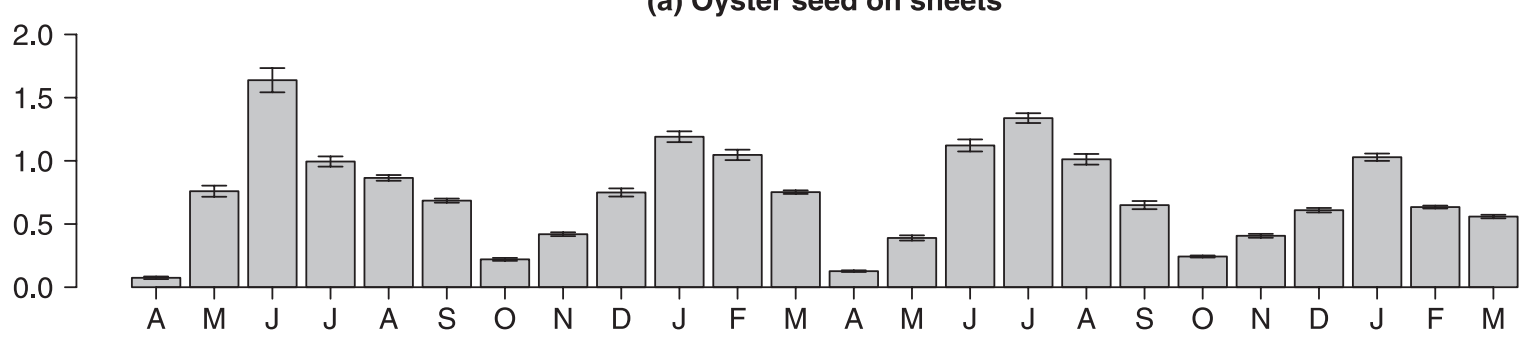

(b) Oyster scars on sheets

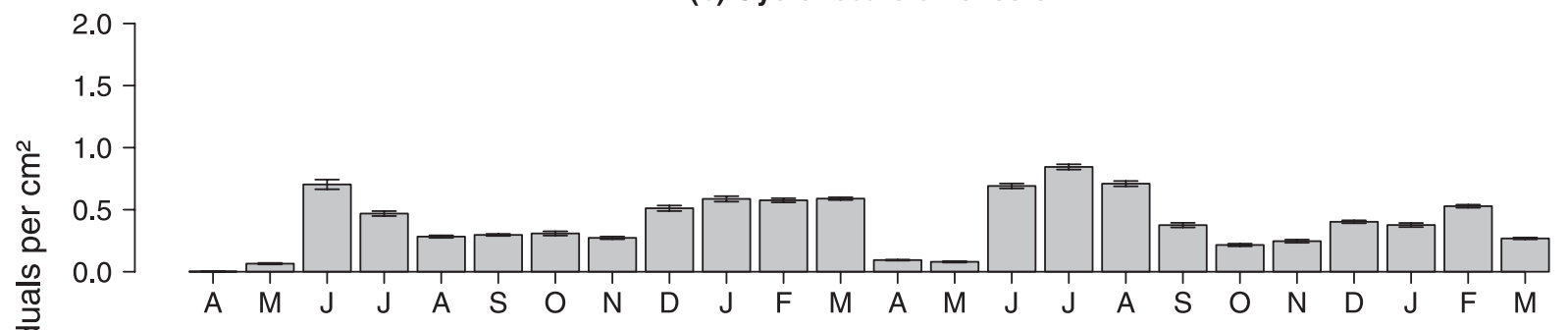

(c) Oyster seed on bottles

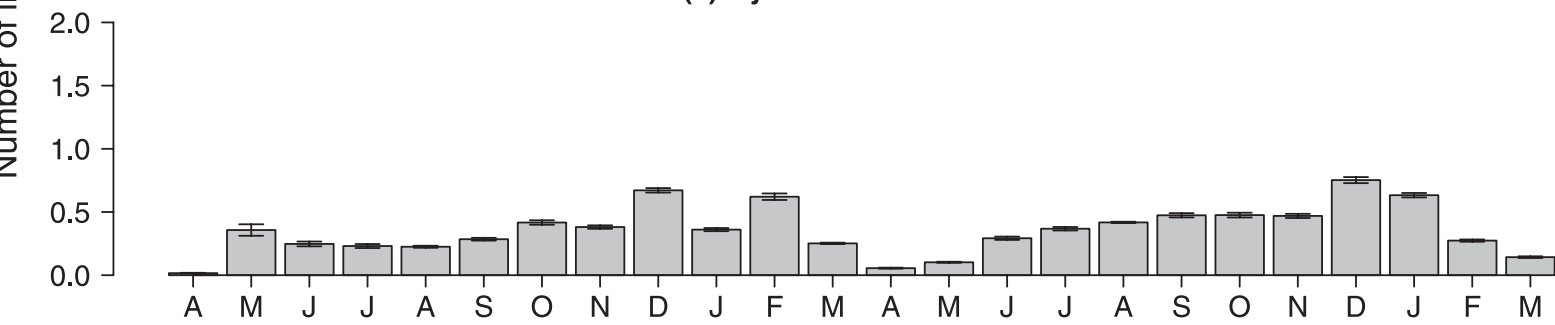

$\left.\begin{array}{l}2.0 \\ 1.5 \\ 1.0 \\ 0.5 \\ 0.0\end{array}\right]$

(d) Oyster scars on bottles

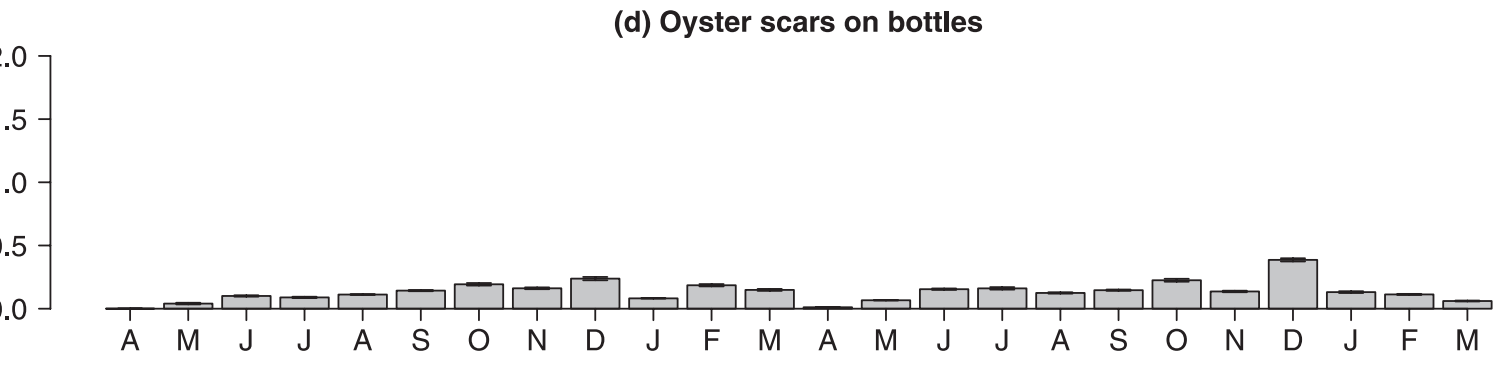

Month (April 2002-March 2004)

Figure 2 - Mean monthly density ( \pm s.e.) of oyster seed and scars on sheets $(a, b)$ and bottles (c,d), respectively, between April 2002 and March 2004, at Ilha Canela.

between inside and outside being greater in the dry season (significant interaction, see Table 3, Figure 4d). Barnacle density on bottles was significantly higher in the wet season and on the outside of bottles (Table 3 , Figure $5 c$ ). There was no seasonal difference in density of other epibenthic organisms, however, density was significantly greater on the inside of the bottle (Table 3 , Figure $5 d$ ).

Monthly values of seawater salinity in the tidal channel during most of the study period are shown in Table 4. Salinity varied between 22 and 40 and, in general, was lowest during March, April and May.
Salinity was consistently lower at Canela during 2003, coinciding with the appearance of barnacles.

\section{DISCUSSION}

Several native species of Crassostrea occur on the Atlantic and Caribbean coasts of South America, as well as the exotic $C$. gigas (Thunberg, 1793) (Carranza et al., 2009; Melo et al., 2010b). Crassostrea sp. canela is closely related to Indo-Pacific species of the same genus (Varela et al., 2007; Melo et al., 2010a) and 


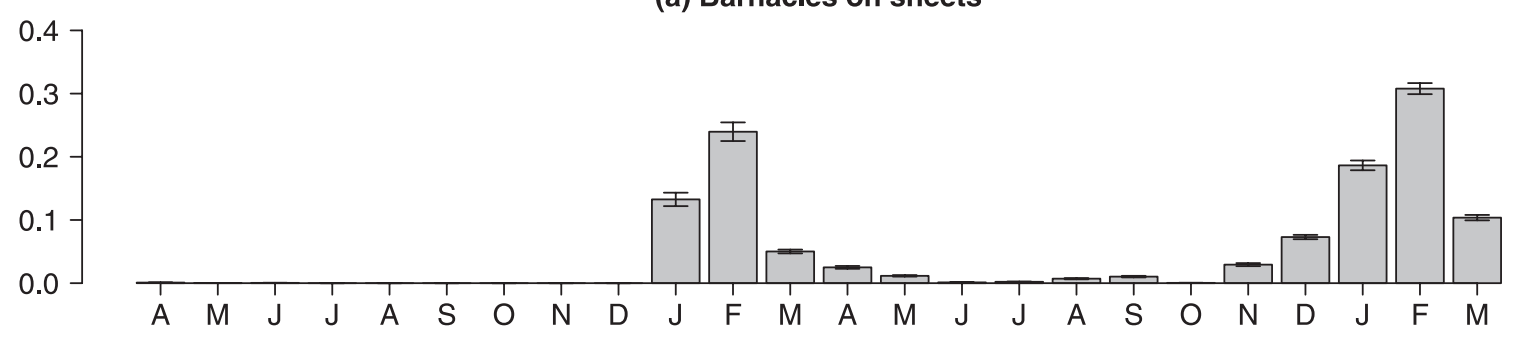

(b) Other epibenthos on sheets

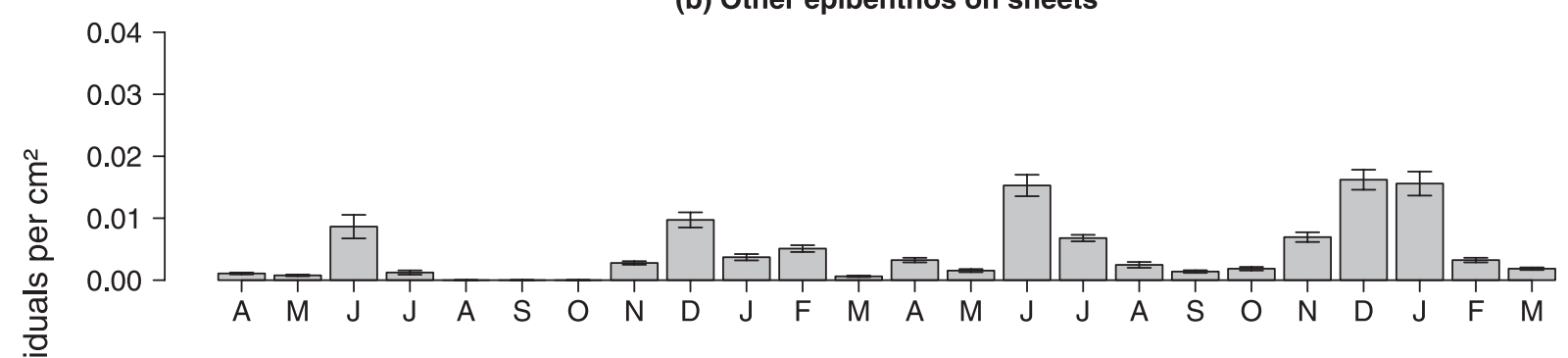

(c) Barnacles on bottles

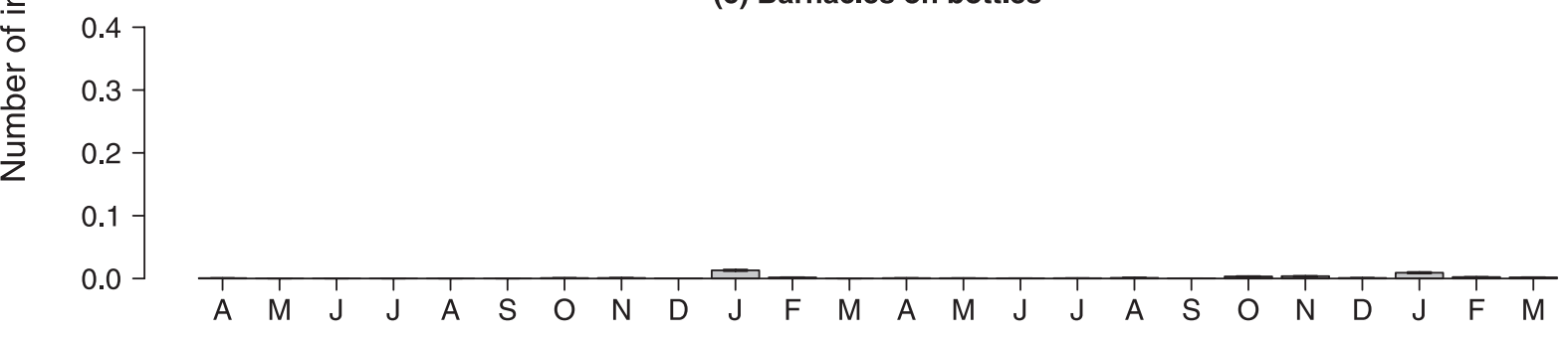

(d) Other epibenthos on bottles
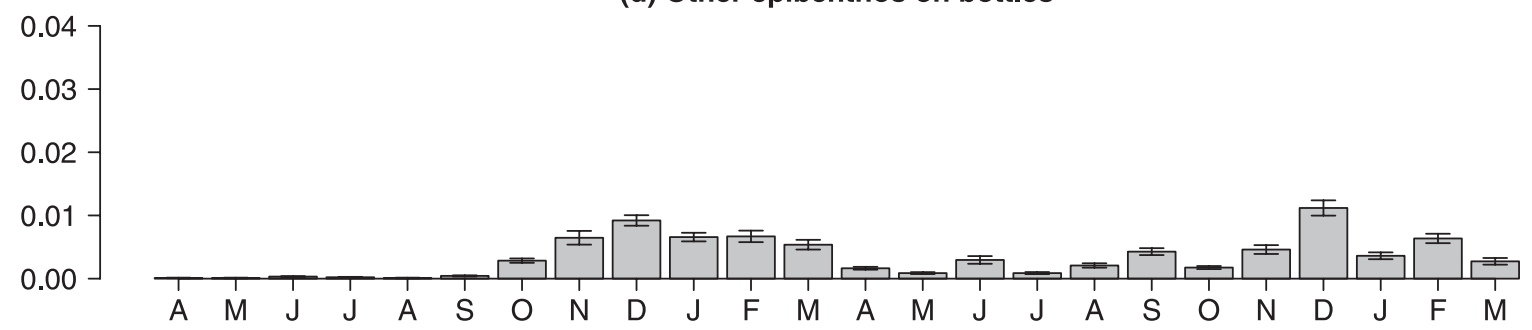

Month (April 2002-March 2004)

Figure 3 - Mean monthly density ( \pm s.e.) of barnacles and other encrusting epibenthos on sheets $(a, b)$ and bottles (c,d), respectively, between April 2002 and March 2004, at llha Canela.

is also found in the wild at Beihai, southern China (Liu et al., 2011). How it arrived at the northern coast of Brazil is unknown, although Varela et al. (2007) suggest it may have been transported by shipping. Oyster growers from Marapanim, Curuça and other municipalities along the Pará coast, report spatfall of Crassostrea sp. canela at these locations but as this oyster does not grow very large, there is concern that it may negatively affect efforts to culture Crassostrea gasar (Author, pers. obs.).

The regular and predictable settlement pattern of Crassostrea sp. canela may indicate proximity to as yet unknown adult populations that may occur on calcareous algal substrates (Matthews \& Kempf, 1970) in the subtidal region. The Asian oyster Crassostrea ariakensis (Fujita, 1913) occurs predominantly in subtidal habitats within its natural range and, in mesocosm experiments, is less tolerant of intertidal exposure than Crassostrea virginica (Gmelin, 1791) (Kingsley-Smith \& Luckenbach, 2008).

The year-round pattern of settlement of Crassostrea sp. canela observed in the present study is remarkably regular and predictable. Settlement in C. gasar and C. rhizophorae may also be year round 
Table 2 - F values from ANOVAs of densities of total epibenthos, oyster seed, oyster scars, barnacles and other epibenthos between seasons (Wet and Dry) and surface type (Concave and Convex) on sheets, between April 2002 and March 2004, at Ilha Canela. Oyster seed and Barnacle data were $\log _{10}(x+1)$ transformed before analysis. $d f=$ degrees of freedom, ${ }^{*}=p<0.05,{ }^{* *}=p<0.01,{ }^{* * *}=p<0.001$.

\begin{tabular}{lcccccc}
\hline \hline $\begin{array}{c}\text { Source of } \\
\text { variation }\end{array}$ & df & $\begin{array}{c}\text { Total } \\
\text { epibenthos }\end{array}$ & Seed & Scars & Barnacles & $\begin{array}{c}\text { Other } \\
\text { epibenthos }\end{array}$ \\
\hline Season (S) & 1 & $6.05^{*}$ & $4.89 *$ & 2.07 & $229.16 * * *$ & 1.12 \\
Surface type (T) & 1 & 1.37 & 2.18 & 0.32 & 0.17 & 0.06 \\
Interaction (SxT) & 1 & 0.35 & 0.0022 & 0.04 & 0.60 & 0.10 \\
Residuals & 956 & & & & & \\
\hline \hline
\end{tabular}

(Afinowi, 1984; Nascimento, 1991; Boehs \& Absher, 1996; Christo \& Absher, 2006; Nalesso et al., 2008) but is usually greater and/or restricted to the dry, high salinity season (Sandison, 1966; Pereira et al., 1988; Alvarenga \& Nalesso, 2006; Marques-Silva et al., 2006; Nalesso et al., 2008). Abundance and survival of larvae of C. rhizophorae and C. gasar are also greater when water temperatures are higher (Lemos et al., 1994; Christo \& Absher, 2006). Salinity at Ilha Canela (22-40) varies much less than in the nearby Caeté estuary (Diele \& Simith, 2006; 0-39). Spatfall of Crassostrea sp. canela always occurred, even during the wettest months (February to May), thus larvae of Crassostrea sp. canela appear to prefer a higher range of salinities. Melo et al. (2010a) reported Crassostrea sp. canela from the Furo do Meio tidal creek in January 2004, when salinity can be as high as 30 (MarquesSilva 2006), despite the onset of the rainy season at

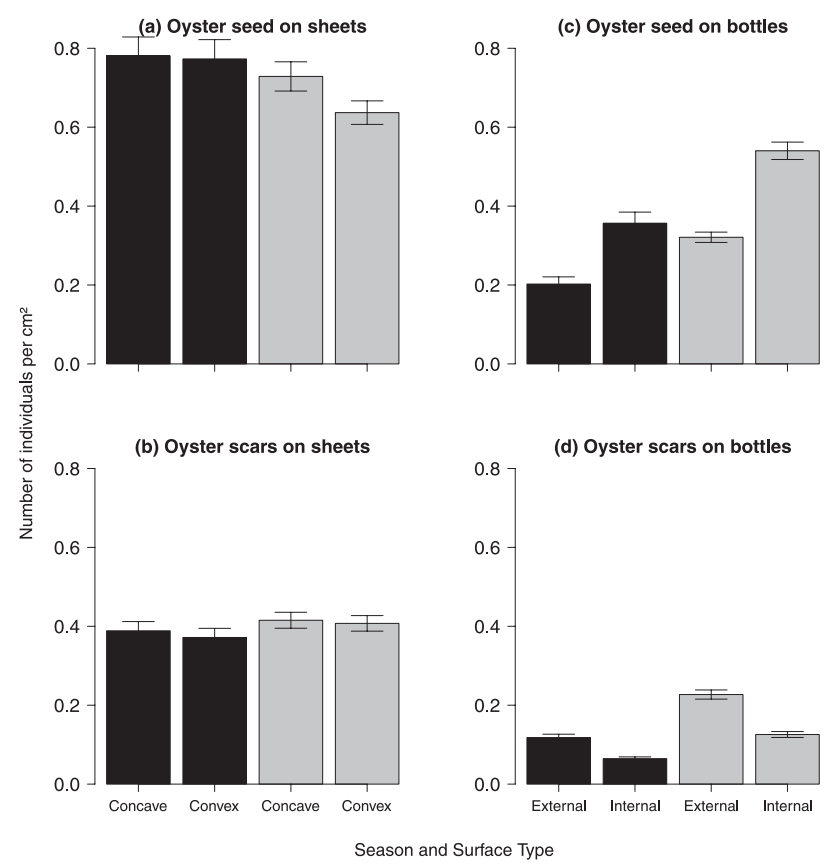

Figure 4. Mean density ( \pm s.e.) of oyster seed and scars on concave and convex surfaces of sheets $(a, b)$ and on external and internal surfaces of bottles $(c, d)$, respectively, during the wet (black bars) and dry (grey bars) seasons, between April 2002 and March 2004, at Ilha Canela. this time. Larvae of C. gasar from West Africa have been reported to tolerate variation in a lower range: 0-15 (Sandison, 1966), 10-25 (Ansa \& Bashir, 2007) and 6-24 (Afinowi, 1984). In Brazil, no spatfall of $C$. rhizophorae and $C$. gasar occurs during the wet season in the nearby Caeté mangrove estuary, when salinity is consistently below 10 (Diele \& Simith, 2006) and often near zero (Marques-Silva et al., 2006; Beasley et al., 2010). Seed collection of $C$. rhizophorae and $C$. gasar is lower below salinities of 19 and 25, respectively, in Brazilian mangrove estuaries (Nascimento, 1991). Thus, the wise choice of sites and or periods for employing seed collectors, in relation to salinity, may reduce interference of Crassostrea sp. canela in C. gasar seed collection. Differences in settlement of both species with regard to salinity should be further investigated.

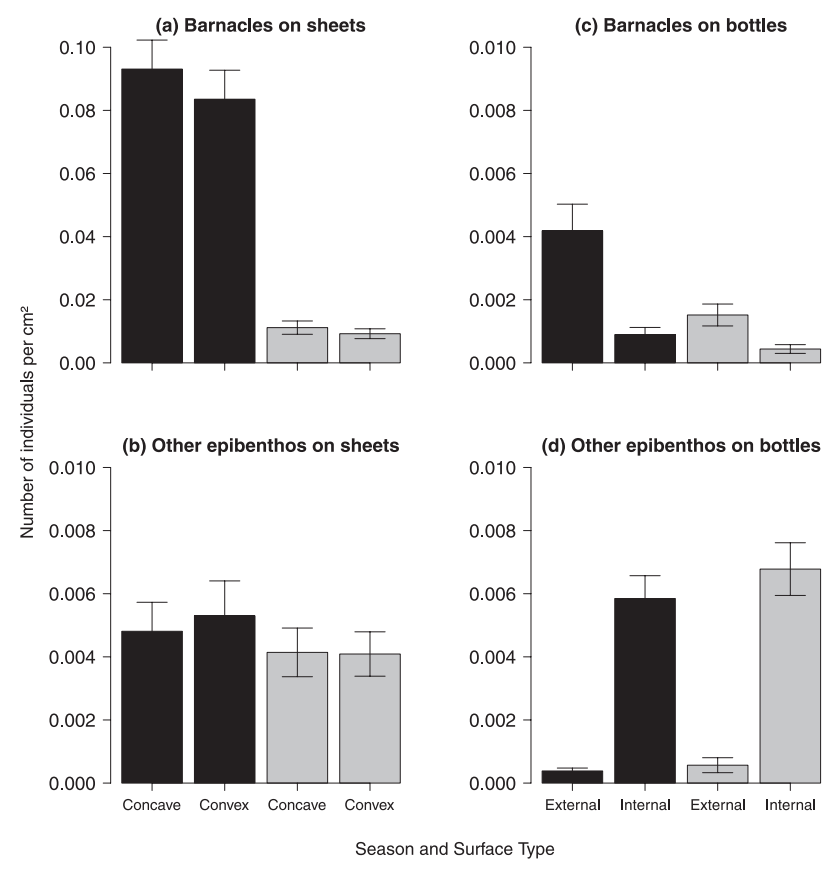

Figure 5. Mean density ( \pm s.e.) of barnacles and other encrusting epibenthos on concave and convex surfaces of sheets $(a, b)$ and on external and internal surfaces of bottles (c,d), respectively, during the wet (black bars) and dry (grey bars) seasons, between April 2002 and March 2004, at Ilha Canela. 
Table 3 - F values from ANOVAs of densities of total epibenthos, oyster seed, oyster scars, barnacles and other epibenthos between seasons (Wet and Dry) and surface type (Inside and Outside) on bottles, between April 2002 and March 2004, at Ilha Canela. Barnacle and Other epibenthos data were $\log _{10}(x+1)$ transformed before analysis. $d f=$ degrees of freedom, ${ }^{*}=p<0.05,{ }^{* *}=p<0.01,{ }^{* * *}=p<0.001$.

\begin{tabular}{lcccccc}
\hline \hline $\begin{array}{l}\text { Source of } \\
\text { variation }\end{array}$ & df & $\begin{array}{c}\text { Total } \\
\text { epibenthos }\end{array}$ & Seed & Scars & Barnacles & $\begin{array}{c}\text { Other } \\
\text { epibenthos }\end{array}$ \\
\hline Season (S) & 1 & $80.33 * * *$ & $51.24 * * *$ & $102.16 * * *$ & $6.83 * *$ & 1.01 \\
Surface type (T) & 1 & $18.53 * * *$ & $78.32 * * *$ & $84.53 * * *$ & $19.89 * * *$ & $210.64 * * *$ \\
Interaction (SxT) & 1 & 0.15 & 2.37 & $8.07 * *$ & 1.2 & 3.14 \\
Residuals & 476 & & & & & \\
\hline \hline
\end{tabular}

Freshwater discharge along the Pará coast is very high during the wet season (Dittmar \& Lara, 2001; Souza-Filho et al., 2009) and influences water flow (Cohen et al., 1999) and water chemistry (Cohen et al., 1999; Schwendenmann et al., 2006). Water flow and turbulence may influence settlement of marine larvae (Abelson \& Denny, 1997), including Crassostrea virginica (Turner et al., 1994; Nestlerode et al., 2007). The low densities of both settlers and scars of Crassostrea sp. canela in April, May, September and October may be due to turbulence and high loads of suspended solids that interfere with settlement, as a result of strong equinoctial spring tides (Souza-Filho et al., 2006). As $73 \%$ of the annual ca. $2500 \mathrm{~mm}$ of rain falls between January and April, the latter being the month of peak freshwater discharge (Souza-Filho et al., 2009), relatively low salinity may also reduce larval settlement in April and May.

Mean densities of oyster seed of Crassostrea $\mathrm{sp}$. canela are generally lower than the $1 \mathrm{~cm}^{-2}$ for $C$. gasar on plastic surfaces in the Niger delta (Afinowi, 1984) but are close to the range of $0.06-0.12$ individuals $\mathrm{cm}^{-2}$ observed by Ajana (1979) for the same species. Densities of Crassostrea sp. canela seed are much greater than those of $C$. rhizophorae reported by Alvarenga \& Nalesso (2006) from southeastern Brazil (0.0763 to $\left.0.2041 \mathrm{~cm}^{-2}\right)$ and Buitrago \& Alvarado (2005) from Venezuela $\left(0.004\right.$ to $0.149 \mathrm{~cm}^{-2}$ ). Settlement densities of Ostrea lurida Carpenter 1864 from California ranged from 0.011 to $0.118 \mathrm{~cm}^{-2}$ (Seale \& Zacherl, 2009). Thus, Crassostrea sp. canela appears to be relatively abundant and may be a potentially strong competitor for space on artificial collectors deployed for obtaining C. gasar seed.

Settlement of oysters has been recorded on an enormous array of artificial and natural substrates
(Ajana, 1979; Afinowi, 1984; Gilles, 1992; Baker, 1997; Saoud et al., 2000; Devakie \& Ali, 2002; Buitrago \& Alvarado, 2005; Nalesso et al., 2008). Crassostrea larvae have been observed settling preferentially on both rough (Baker, 1997) and smooth (Crisp, 1967) surfaces of shells, for example. Schaefer (1937) noted that substrate smoothness may not be important considering the size of larvae in relation to particles of sand, other encrusting organisms, etc. that may accumulate on collectors. Collectors conditioned with water containing adult oysters have been successful in inducing settlement (Crisp, 1967; Hirata, 1998). Thus, plastic substrates are considered effective seed collectors (Baud et al., 1991), particularly when conditioned with oyster shell remnants (Devakie \& Ali, 2002) and are flexible so seed are easily removed and the sheets reused (Buitrago \& Alvarado, 2005).

Crassostrea sp. canela seed was more abundant on the relatively more exposed sheets in the wet season as greater humidity, cloud cover and rainfall reduce temperatures and the effects of desiccation. Shading and/or the absence of sedimentation may lead to higher densities of settlers (Schaefer, 1937; Saoud et al., 2000; Nalesso et al., 2008). The plastic sheets used in our experiment were transparent and thus did not provide shade. Where sedimentation rates are high, oxygen levels may decline (Mann, 2000) and settlement of oysters may be greatly reduced in such conditions Baker \& Mann (1992). The vertical arrangement of sheets in the present study may have reduced sedimentation on both surfaces of the majority of sheets, contributing to similar densities on both the convex and concave surfaces of sheets. Bottles appear to provide a refuge from desiccation and predators for Crassostrea sp. canela seed during the dry season with greater abundance and lowest mortality inside bottles.

Table 4 - Sea water salinity in the tidal channel at Ilha Canela between February 2002 and January 2004. Missing data are indicated by "-".

\begin{tabular}{lllllllllllll}
\hline \hline Year and Month & $\mathbf{J}$ & $\mathbf{F}$ & $\mathbf{M}$ & $\mathbf{A}$ & $\mathbf{M}$ & $\mathbf{J}$ & $\mathbf{J}$ & $\mathbf{A}$ & $\mathbf{S}$ & $\mathbf{O}$ & $\mathbf{N}$ & $\mathbf{D}$ \\
\hline 2002 & & 32 & 33 & 23 & 30 & 40 & 34 & 34 & 35 & 34 & 32 & 34 \\
2003 & 29 & 29 & 24 & 28 & 22 & 31 & 31 & 32 & 31 & 34 & 31 & 31 \\
2004 & 30 & - & - & & & & & & & & & \\
\hline \hline
\end{tabular}


Barnacles appear to be more resistant to desiccation (Nascimento, 1991; Saoud et al., 2000) and there is evidence that they may displace young oysters (Osman et al., 1989). Crassostrea sp. canela appears not to reach a large size (Author, pers. obs.) and so may be more susceptible to undercutting from barnacles. Other Crassostrea, including C. gasar, are able to successfully settle in high numbers over dense patches of barnacles (Osman et al., 1989; Gilles, 1992). Trials should be carried out with collectors preconditioned with a limited covering of barnacles that may help seed of $C$. gasar to establish whilst eliminating those of Crassostrea sp. canela.

Other epibenthic oysters and bivalves, tubedwelling polychaetes, barnacles, bryozoans and other colonial organisms, and algae (Afinowi, 1984; Pereira et al., 1988; Osman et al., 1989; Nascimento, 1991; Gilles, 1992; Saoud et al., 2000; Buitrago \& Alvarado, 2005; Alvarenga \& Nalesso, 2006) may compete with oysters seed for space and/or food. This so called "fouling community" may be managed by removing collectors from the water for three hours per week (Buitrago \& Alvarado, 2005). However, encrusting epibenthos may attract oyster larvae (Osman et al., 1989) and our results suggest a positive correlation between the density of other epibenthos and that of oyster seed. Limited development of the fouling fauna, such as barnacles, may help attract seed of target species and, as mentioned above, may have the potential to eliminate that of undesirable ones.

The present study shows that spatfall of Crassostrea sp. canela is abundant and regular at Ilha Canela and may thus pose difficulties for oyster growers in Pará. Trials with seed collectors deployed at specific times and places to detect peaks in numbers of larvae of this exotic Crassostrea may help reduce the loss of valuable $C$. gasar seed. More efficient collectors, such as those previously conditioned with conspecifics (Devakie \& Ali, 2002) or limited epibenthos development, as well as the restoration of native oyster beds (Bartol \& Mann, 1997) may promote greater spatfall of $C$. gasar, the target species for oyster growers in the region.

\section{ACKNOWLEDGEMENTS}

We are grateful to Cinthia Arruda, Carlos Santos Filho, Marcelo Victor Serejo, João Braúllio de Luna Sales and Tiago Soares for help in the field. DCLG and CPG were supported by undergraduate scholarships (Iniciação Científica) from the Conselho Nacional de Desenvolvimento Científico e Tecnológico. This study was carried out as part of the Mangrove Dynamics and Management Project, a joint German-Brazilian cooperative scientific program.

\section{REFERENCES}

Abelson, A. \& Denny, M. 1997. Settlement of marine organisms in flow. Annu. Rev. Ecol. Syst. 28:317-339.

Afinowi, A.M. 1984. The mangrove oyster, Crassostrea gasar culture and potential in the Niger delta (Nigeria). Technical Paper 14. Nigerian Institute for Oceanography and Marine Research, Lagos, Nigeria. 13p.

Ajana, A.M. 1979. Preliminary investigation into some factors affecting the settlement of the larvae of the mangrove oyster Crassostrea gasar (Adanson) in the Lagos lagoon. Malacologia 18:271-275.

Alongi, D.M. 2002. Present state and future of the world's mangrove forests. Environ. Conserv. 29:331-349.

Alvarenga, L. \& Nalesso, R.C. 2006. Preliminary assessment of the potential for mangrove oyster cultivation in Piraquê-açu river estuary (Aracruz, ES). Braz. Arch. Biol. Technol. 49:163-169.

Amaral, D.D., Santos, J.U., Bastos, M.N. \& Costa, D.C. 2001. A vegetação da Ilha Canela, município de Bragança Pará, Brazil. Bol. Mus. Para. Emílio Goeldi Sér. Bot. 17:389-402.

Ansa, E.J. \& Bashir, R.M. 2007. Fishery and culture potential of the mangrove oyster (Crassostrea gasar) in Nigeria. Res. J. Biol. Sci. 2:392-394.

Baker, P. 1997. Settlement site selection by oyster larvae, Crassostrea virginica: evidence for geotaxis. J. Shellfish Res. 16:125-128.

Baker, S.M. \& Mann, R. 1992. Effects of hypoxia and anoxia on larval settlement, juvenile growth, and juvenile survival of the oyster Crassostrea virginica. Biol. Bull. 182:265-269.

Bartol, I.K. \& Mann, R. 1997. Small-scale settlement patterns of the oyster Crassostrea virginica on a constructed intertidal reef. Bull. Mar. Sci. 61:881-897.

Baud, J.-P., Jolly, C. \& Bodoy, A. 1991. Improvement of remote setting of the Pacific oyster (Crassostrea gigas) on French plastic pipes. Counc. Meet. Int. Counc. Explor. Sea K29:1-12.

Beasley, C.R., Fernandes, M.E.B., Figueira, E.A.G., Sampaio, D.S., Melo, K.R. \& Barros, R.S. 2010. Mangrove infauna and sessile epifauna. In: SaintPaul, U. \& Schneider, H. (eds.) Mangrove dynamics and management in north Brazil. Springer, Berlin, Heidelberg. 109-123pp.

Boehs, G. \& Absher, T.M. 1996. Variação temporal de larvas de ostras do gênero Crassostrea 
Sacco, 1897 (Ostreoida: Ostreidae) na Baía de Paranaguá, Paraná. Braz. Arch. Biol. Technol. 39:903-910.

Brumbaugh, R.D. \& Coen, L.D. 2009. Contemporary approaches for small-scale oyster reef restoration to address substrate versus recruitment limitation: a review and comments for the Olympia oyster, Ostrea lurida Carpenter 1864. J. Shellfish Res. 28:147-161.

Buitrago, E. \& Alvarado, D. 2005. A highly efficient oyster spat collector made with recycled materials. Aquac. Eng. 33:63-72.

Carranza, A., Defeo, O. \& Beck, M. 2009. Diversity, conservation status and threats to native oysters (Ostreidae) around the Atlantic and Caribbean coasts of South America. Aquat. Conserv. Mar. Freshw. Ecosyst. 19:344-353.

Christo, S.W. \& Absher, T.M. 2006. Reproductive period of Crassostrea rhizophorae (Guilding, 1828) and Crassostrea brasiliana (Lamarck, 1819) (Bivalvia: Ostreidae) in Guaratuba Bay, Paraná, Brazil. J. Coast. Res. 39:1215-1218.

Cohen, M.C.L., Lara, R.J., Ramos, J.F. d.F. \& Dittmar, T. 1999. Factors influencing the variability of $\mathrm{Mg}, \mathrm{Ca}$ and $\mathrm{K}$ in waters of a mangrove creek in Bragança, North Brazil. Mangr. Salt Marsh. 3:9-15.

Crisp, D.J. 1967. Chemical factors inducing settlement in Crassostrea virginica (Gmelin). J. Anim. Ecol. 36:329-335.

Dame, R.F. 1996. Ecology of marine bivalves. An ecosystem approach. CRC Press, Boca Raton, 254p.

Devakie, M.N. \& Ali, A.B. 2002. Effective use of plastic sheet as substrate in enhancing tropical oyster (Crassostrea iredalei Faustino) larvae settlement in the hatchery. Aquaculture 212:277-287.

Diele, K. \& Simith, D.J.B. 2006. Salinity tolerance of northern Brazilian mangrove crab larvae, Ucides cordatus (Ocypodidae): Necessity for larval export? Estuar. Coast. Shelf Sci. 68:600-608.

Dittmar, T. \& Lara, R.J. 2001. Do mangroves rather than rivers provide nutrients to coastal environments south of the Amazon River? Evidence from longterm flux measurements. Mar. Ecol. Prog. Ser. 213:67-77.

Ellison, A.M. 2008. Managing mangroves with benthic biodiversity in mind: Moving beyond roving banditry. J. Sea Res. 59:2-15.

Gilles, S. 1992. Observations sur le captage et la croissance de l'huitre creuse ouest-africaine, Crassostrea gasar, en Casamance, Senegal. Actes de Colloques, IFREMER 14:71-88.

Glaser, M. 2003. Interrelations between mangrove ecosystem, local economy and social sustainability in Caete Estuary, North Brazil. Wetl. Ecol. Manag. 11:265-272.

Glaser, M. \& Oliveira, R.D. 2004. Prospects for the co-management of mangrove ecosystems on the North Brazilian coast. Whose rights, whose duties and whose priorities? Nat. Resour. Forum 28:224-233.

Hirata, Y. 1998. Effective pretreatments of spatcollectors for induced settlement of the Pacific oyster, Crassostrea gigas. Nippon Suisan Gakkaishi 64:610-617.

Ihaka, R. \& Gentleman, R. 1996. R: a language for data analysis and graphics. J. Comput. Graph. Stat. 5:299-314.

Kathiresan, K. \& Bingham, B.L. 2001. Biology of mangroves and mangrove ecosystems. Adv. Mar. Biol. 40:81-251.

Kingsley-Smith, P.R. \& Luckenbach, M.W. 2008. Postsettlement survival and growth of the Suminoe oyster, Crassostrea ariakensis, exposed to simulated emersion regimes. J. Shellfish Res. 27:609-618.

Krause, G. \& Glaser, M. 2003. Co-evolving geomorphical and socio-economic dynamics in a coastal fishing village of the Bragança region (Pará, North Brazil). Ocean Coast. Manag. 46:859-874.

Krause, G., Schories, D., Glaser, M. \& Diele, K. 2001. Spatial patterns of mangrove ecosystems: the Bragantinian mangroves of northern Brazil (Bragança, Pará). Ecotropica 7:93-107.

Lapègue, S., Boutet, I., Leitão, A., Heurtebise, S., Garcia, P., Thiriot-Quiévreux, C. \& Boudry, P. 2002. Trans-Atlantic distribution of a mangrove oyster species revealed by $16 \mathrm{~S} \mathrm{mtDNA}$ and karyological analyses. Biol. Bull. 202:232-242.

Lazoski, C., Gusmão, J., Boudry, P. \& Solé-Cava, A.M. 2011. Phylogeny and phylogeography of Atlantic oyster species: evolutionary history, limited genetic connectivity and isolation by distance. Mar. Ecol. Prog. Ser. 426:197-212.

Lemos, M.B.N., Nascimento, I.A., Araújo, M.M.S., Pereira, S.A., Bahia, I. \& Smith, D.H. 1994. The combined effects of salinity, temperature, antibiotic and aeration on larval growth and survival of the mangrove oyster, Crassostrea rhizophorae. J. Shellfish Res. 13:187-192.

Liu, J., Li, Q., Kong, L., Yu, H. \& Zheng, X. 2011. Identifying the true oysters (Bivalvia: Ostreidae) with mitochondrial phylogeny and distance-based DNA barcoding. Mol. Ecol. Resour. 11(5): 820-830.

Mann, K.H. 2000. Estuarine benthic systems. In: Mann, K.H. (ed.) Ecology of coastal waters with implications for management. Blackwell Scientific Publishing, Oxford. 118-135pp. 
Marques-Silva, N.S., Beasley, C.R., Gomes, C.P., Gardunho, D.C.L., Tagliaro, C.H., Schories, D. \& Mehlig, U. 2006. Settlement dynamics of the encrusting epibenthic macrofauna in two creeks of the Caeté mangrove estuary (North Brazil). Wetl. Ecol. Manag. 14:67-78.

Matthews, H.R. \& Kempf, M. 1970. Moluscos marinhos do Norte e Nordeste do Brasil. II Moluscos do Arquipélago de Fernando de Noronha (com algumas referências ao Atol das Rocas). Arq. Ciênc. Mar 10:1-53.

Melo, A.G.C., Varela, E.S., Beasley, C.R., Schneider, H., Sampaio, I., Gaffney, P.M., Reece, K.S. \& Tagliaro, C.H. 2010a. Molecular identification, phylogeny and geographic distribution of Brazilian mangrove oysters (Crassostrea). Genet. Mol. Biol. 33:564-572.

Melo, C.M.R., Silva, F.C., Gomes, C.H.A.M., SoleCava, A.M. \& Lazoski, C. 2010b. Crassostrea gigas in natural oyster banks in southern Brazil. Biol. Invasions 12:441-449.

Nalesso, R.C., Paresque, K., Piumbini, P.P., Tonini, J.F.R., Almeida, L.G. \& Níckel, V.M. 2008. Oyster spat recruitment in Espírito Santo state, Brazil, using recycled materials. Braz. J. Oceanogr. 56:281-288.

Nascimento, I.A. 1991. Crassostrea rhizophorae (Guilding) and C. brasiliana (Lamarck) in South and Central America. In: Menzel, W. (ed.) Estuarine and marine bivalve mollusk culture. CRC Press, Boca Raton. 125-134pp.

Nestlerode, J.A., Luckenbach, M.W. \& O'Beirn, F.X. 2007. Settlement and survival of the oyster Crassostrea virginica on created oyster reef habitats in Chesapeake bay. Restor. Ecol. 15:273-283.

Nishida, A.K., Nordi, N. \& da Nóbrega Alves, R. 2006. Mollusc gathering in NorthEast Brazil: an ethnoecological approach. Hum. Ecol. 34:133-145.

Osman, R.W., Whitlatch, R.B. \& Zajac, R.N. 1989. Effects of resident species on recruitment into a community - larval settlement versus postsettlement mortality in the oyster Crassostrea virginica. Mar. Ecol. Prog. Ser. 54:61-73.

Pereira, O.M., Akaboshi, S. \& Soares, F.C. 1988. Cultivo experimental de Crassostrea brasiliana (Lamarck, 1819) no canal da Bertioga, São Paulo, Brasil (235' 30"S, 4513'42”W). Bol. Inst. Pesca (São Paulo) 151:55-65.

Pie, M.R., Ribeiro, R.O., Boeger, W.A., Ostrensky, A., Falleiros, R.M. \& Angelo, L. 2006. A simple PCR-RFLP method for the discrimination of native and introduced oyster species (Crassostrea brasiliana, C. rhizophorae and C. gigas; Bivalvia:
Ostreidae) cultured in Southern Brazil. Aquac. Res. 37:1598-1600.

Rodrigues, A.A.F. 2007. Priority areas for conservation of migratory and resident waterbirds on the coast of Brazilian Amazonia. Rev. Bras. Ornitol. 15:209-218.

R-project 2011. The R Project for Statistical Computing. http://www.r-project.org. Accessed 06/30/2011.

Sampaio, D.S. 2007. Energia que vem da ostra: do extrativismo para o cultivo. In: Duarte, R.B. d.A. (ed.) Histórias de sucesso: agronegócios: aqüicultura e pesca. SEBRAE, Brasília. 143-160pp.

Sandison, E.E. 1966. The effect of salinity fluctuations on the life cycle of Gryphaea gasar ((Adanson) Dautenberg) in Lagos Harbour, Nigeria. J. Anim. Ecol. 35:379-389.

Saoud, I.G., Rouse, D.B., Wallace, R.K., Howe, J. \& Page, B. 2000. Oyster Crassostrea virginica spat settlement as it relates to the restoration of Fish River Reef in Mobile Bay, Alabama. J. World Aquacult. Soc. 31:640-650.

Schaefer, M.B. 1937. Attachment of the larvae of Ostrea gigas, the Japanese oyster, to plane surfaces. Ecology 18:523-527.

Schwendenmann, L., Riecke, R. \& Lara, R. 2006. Solute dynamics in a North Brazilian mangrove: the influence of sediment permeability and freshwater input. Wetl. Ecol. Manag. 14:463-475.

Seale, E.M. \& Zacherl, D.C. 2009. Seasonal settlement of Olympia oyster larvae, Ostrea lurida Carpenter 1864 and its relationship to seawater temperature in two southern California estuaries. J. Shellfish Res. 28:113-120.

de Sousa, E.B., da Costa, V.B., Pereira, L.C.C. \& da Costa, R.M. 2008. Microfitoplâncton de águas costeiras amazônicas: Ilha Canela (Bragança, PA, Brasil). Acta Bot. Bras. 22:626-636.

Souza-Filho, P.W.M., Lessa, G.C., Cohen, M.C.L., Costa, F.R. \& Lara, R.J. 2009. The subsiding macrotidal barrier estuarine system of the eastern Amazon coast, northern Brazil. In: Dillenburg, S.F. \& Hesp, P.A. (eds.) Geology and geomorphology of Holocene coastal barriers of Brazil. Springer, Berlin \& Heidelberg. 347-375pp.

Souza-Filho, P.W.M., Martins, E. d.S.F. \& Ribeiro da Costa, F. 2006. Using mangroves as a geological indicator of coastal changes in the Bragança macrotidal flat, Brazilian Amazon: A remote sensing data approach. Ocean Coast. Manag. 49:462-475.

Turner, E.J., Zimmerfaust, R.K., Palmer, M.A., Luckenbach, M. \& Pentcheff, N.D. 1994. Settlement of oyster (Crassostrea virginica) larvae - effects of water-flow and a water-soluble chemical cue. Limnol. Oceanogr. 39:1579-1593. 
Varela, E.S., Beasley, C.R., Schneider, H., Sampaio, I., Marques-Silva, N.D.S. \& Tagliaro, C.H. 2007. Molecular phylogeny of mangrove oysters (Crassostrea) from Brazil. J. Molluscan Stud. 74:103-109.

Wolff, M., Koch, V. \& Isaac, V. 2000. A trophic flow model of the Caeté mangrove estuary (North
Brazil) with considerations for the sustainable use of its resources. Estuar. Coast. Shelf Sci. 50:789-803.

Submetido: Março/2011 Revisado: Maio/2011 Aceito: Agosto/2011 